\title{
AZ ÖNKORMÁNYZATI INTÉZMÉNYRENDSZER ÁTALAKULÁSÁNAK LEHETSÉGES IRÁNYAI
}

\author{
(Possible directions of the transformation of the institutional system of \\ local governments)
}

\section{FINTA ISTVÁN}

Az államháztartási reform, a non-profit szervezetek kialakulása, az önkormányzatok és intézményeik kedvezótlen gazdasági helyzete, sok olyan problémát vet fel, amelyek a korábbiakban nem jelentkeztek ilyen kiélezett formában, s így elkerülték a szakemberek figyelmét.

A dolgozat célja, hogy empirikus kutatások segítségével bemutassa az önkormányzatok legfontosabb intézményeit általánosan jellemzö gondokat. Ennek érdekében egy közép, egy kis lélekszámú város, valamint négy egymástól eltérö számú lakossággal rendelkező község önkormányzatának és intézményeinek költségvetése, mindennapi múködése került vizsgálat alá.

A vizsgálatok eredményei megerỏsítették azokat az elméleti megállapításokat, amelyek fơként a költségvetési intézmények vezetési-szervezési, gazdálkodási tevékenységére yonatkoznak. A dolgozat első részében ezekről az elvekről elméletekről esik szó.

\section{Szervezési elvek, megoldások a profit és non-profit szférában}

A szervezési elvek és szervezeti formák tanulmányozása, tudományos szintủ értékelése több tudományág (közgazdaságtan, jogtudomány) fontos részterületét képezi. Legintenzívebb fejlődés talán a profitorientált társaságokra, vállalatokra vonatkozó elméletek tekintetében tapasztalható. Emellett azonban létrejoott - és hazánkban is fokozatosan tért hódít - a non-profit menedzsment, és az e szférát szervezeti formák szerint tanulmányozó tudomány. A for profit és a non-profit szervezetek közé helyezhetök az állam illetve az önkormányzatok által fenntartott ún. költségvetési intézmények. Ezen intézményrendszer tekintetében nem tapasztalható olyan irányú és mértékủ érdeklődés, amely új szervezeti formák, szervezési elvek kidolgozását eredményezte volna. Ez a probléma napjainkban különösen aktuális, hiszen - egy példával élve - nem feltétlenül az intézmények bezárása, összevonása jelenthet egyedüli megoldást akkor, amikor a meglévỏ (és változatlan formában fennmaradó) intézmények struktúrája önmagában pazarló gazdálkodást eredményezhet.

A dolgozat e fejezetében a profit és non-profit szférában alkalmazott olyan szervezési elvekról esik szó, amelyek létezésétól, esetleges adaptációtól nem tekinthet el az, aki a költségvetési intézményrendszer modernizációjával foglalkozik.

A megállapítások nem érvényesek a tisztán közigazgatási közhatalmi szervekre, (rendỏrség, tüzoltóság, polgármesteri hivatalok) a vizsgálódás körébe a különbözó \$zolgáltatást nyújtó, fóként az állami költségvetés által finanszírozott intézmények (oktatási-egészségügyi intézmények) tartoznak. Ezen intézmények szervezeti kereteire yonatkozóan a jogszabályok nagyrészt nem tartalmaznak kötelező elöírást. Épp az 
önkormányzatok számára biztosított többnyire az a széles döntési lehetöség, hogy feladatukat maguk lássák el, akár költségvetési intézményi keretekben, akár a non-profit szférához kapcsolódó közalapítvány formájában, vagy ellátási szerződést kössenek, amelyben a kötelezett a feladatot - szélsö esetben - akár piaci körülmények között is elláthatja.

Jelen pillanatban az önkormányzatok nem használják ki azt a széles választási lehetöséget, amely alkalmat nyújtana arra, hogy az általuk fenntartott intézmények müködési keretei megváltoztassák. A profit szférában a piaci érdek, a társasági törvény, és az egyes adójogszabályok alakítják a tevékenységnek megfelelö szervezeti keretet. A nonprofit intézmények esetén az alapítók és a jogszabály (Ptk. és a társadalmi szervezetekröl szóló törvény) határozza meg, hogy tevékenységüket milyen formában kívánják folytatni. A szervezeti forma megválasztása alapvetö hatást gyakorol a végezni kivaant tevékenység gazdaságossági fokára. A költségvetési intézményekre vonatkozó jogszabályok amennyiben emlitést tesznek - a szervezeti keretekröl föként szakmai szempontok szerint teszik azt. Úgy tünik, a jogalkotás nem veszi figyelembe a gyakorlatban a profit és nonprofit szférában múködő szervezési elveket, amelyek célja a leggazdaságosabb termelés, szolgáltatás nyújtása. A jogszabályok, mint külső környezeti tényezők, igen nagy mélységben befolyásolják a költségvetési intézmények múködését. A profit és non-profit szervezetek szintén a külső környezeti hatásokra adott válaszok alapján különíthetők el egymástól. Ezt a következỏ táblázat kívánja szemléltetni:

\section{TÁBLÁZAT}

For-profit és non-profit szervezetek jellemzöi

(The main characteristics of for-profit and non-profit organisations)

\begin{tabular}{|c|c|c|}
\hline Ismertetōjegyek & A vállalatoknál & A non-profit szervezeteknél \\
\hline 1. Fö célkitüzések & $\begin{array}{l}\text { Biztositani a befektetett } \\
\text { tôke hozamát } \\
\text { (rentábilis/haszon). }\end{array}$ & $\begin{array}{l}\text { Olyan szolgáltatások élvezetéhez juttatni a tagokat, amelyek specifil } \\
\text { igényeket elégítenek ki. Szokásos elnevezés kooperációs vagy kollek } \\
\text { gazdálkodás. }\end{array}$ \\
\hline $\begin{array}{l}\text { 2. A vevőkör } \\
\text { igényeinek kielégítése }\end{array}$ & Lefedni a piaci igényeket & $\begin{array}{l}\text { Lefedni a tagok specifikus igényeit. Azonosság van a tagok és a kliensek, az } \\
\text { a non-profit szervezet szolgáltatásait élvezők között. }\end{array}$ \\
\hline $\begin{array}{l}\text { 3. A döntések } \\
\text { irányítottsága }\end{array}$ & $\begin{array}{l}\text { A döntéseket a piac, a } \\
\text { vevókör magatartása és a } \\
\text { konkurencia irányitja }\end{array}$ & $\begin{array}{l}\text { A szolgáltatásokról maguk a tagok döntenek demokratikusan, al } \\
\text { közvetlenül, akár a választások és a szervek megválasztása, a pénzü } \\
\text { döntések, a csatlakozás vagy a lemondás révén. A non-profit szervezet } \\
\text { teljes egészében vagy részben nem piaci helyzetben müködnek. }\end{array}$ \\
\hline 4. Elöállított javak & $\begin{array}{l}\text { Magán és egyéni javak, } \\
\text { amelyek csak a } \\
\text { kereskedelmi forgalomba } \\
\text { hozhatók és amelyeket csak } \\
\text { a vevô tud felhasználni. }\end{array}$ & $\begin{array}{l}\text { Kollektív javak (amelyekkel élhet pl.: egy szakmai csoport összes tagia, m } \\
\text { azok is akik nem fizetnek tagdijat). Inkább csak ki-vételesen, } \\
\text { elöfordullhatnak egyéni szolgáltatások is, amelyeket a tagok eladhatnak. }\end{array}$ \\
\hline 5. Pénzeszközök & $\begin{array}{l}\text { Befektetett tôke és az } \\
\text { eladásból származó } \\
\text { jövedelem (árak által } \\
\text { történő finanszirozás). }\end{array}$ & $\begin{array}{l}\text { Tagdijakból vagy adókból származó jövedelem (ez utóbbiakat úgy tekint } \\
\text { mint átalánydíjas hozzájárulásokat az elöállított kollektiv javakho } \\
\text { Jövedelmet biztositanak a kinált és eladott szolgáltatások is. }\end{array}$ \\
\hline 6. Munkafaktor & $\begin{array}{l}\text { A munkatársak zömét teljes } \\
\text { munkaidőre alkalmazzák. }\end{array}$ & $\begin{array}{l}\text { Nagymértékủ a tagok önkéntes részvétele a különféle szervezetekb } \\
\text { (bizottságok, alcsoportok stb.) }\end{array}$ \\
\hline 7. Hatékonyság & $\begin{array}{l}\text { A hatékonyságot mindenek } \\
\text { előtt az üzleti forgalom, } \\
\text { piaci részesedés, haszon } \\
\text { tükrözi. }\end{array}$ & $\begin{array}{l}\text { Nincs olyan mutató, amellyel a globális hatékonyság mérhetõ lenne. Nel } \\
\text { konkretizálni a célkitúzéseket és értékelni a teljesitményt. }\end{array}$ \\
\hline
\end{tabular}

Forrás: Farkas 42.0. 
Tevékenységi körüket tekintve a költségvetési intézmények inkább a non-profit szervezetekhez állnak közelebb. A non-profit szervezetek - az ún. viselkedési elméletek egyik csoportja (Alchim és Demsetz 1972, Hansmann 1980) szerint - több negatív tulajdonsággal is rendelkeznek. E szerint a szervezetek profitérdekelt tulajdonosok hiányában aránylag alacsony hatékonysággal dolgoznak. A szervezetet vezető menedzserek a nyereségben nem részesednek, így legfeljebb presztizsük növelése érdekében igyekeznek a költségeket csökkenteni, a ráfordításokat optimalizálni. Nagy valószínúséggel állítható, hogy hatékonyságuk gyenge, épp ezért müködnek olyan ágazatokban, ahol a piac múködése nem optimális. Ezek a vonások ugyanúgy fellelhetök a költségvetési intézményeknél, fủggetlenül attól, hogy azok jó részében még menedzsment sem müködik.

Ugyanakkor a non-profit szervezetek kedvezö vonása, hogy differenciálni tud az egyedi emberi igények szerint. A szolgáltatás annál értékesebb, minél mélyebb a differenciálódás foka. A szervezeti méret nővekedésével a bürokratikus vonások erősödhetnek, amelyek gyengíthetik a szervezetek imént vázolt előnyeit. Megfigyelhető az is, hogy a nagyobb szervezetek inkább utasításokkal irányíthatók, mint közvetett szabályozással, s ez a fejlödés ellenében hat.

Ez utóbbi gondolat már átvezet a profit és non-profit szervezetekben müködő szervezési, vezetési elméletekhez. Ennek egyik legfontosabb eleme napjainkban a koordináció. Ennek oka, hogy „rendkívül diverzifikálódott és differenciálódott környezet közepette kell a vállalatoknak egy rugalmas, ugyanakkor relatíve stabil müködést megvalósítaniuk". (Dobảk 1993) E cél elérését leginkább a koordináció képes biztosítani. Következö táblázat a koordinációs eszközök típusait kívánja bemutatni.

\section{TÁBLÁZAT}

Koordinációs típusok és eszközrendszerek

(Types of coordinations and the most important resources)

\begin{tabular}{|c|c|}
\hline Koordinációs eszköz típusa & Koordinációs eszköz \\
\hline Technokratikus & $\begin{array}{c}\text { Szabályok, szabályzatok, eljárások } \\
\text { Tervek, programok, menetrendek } \\
\end{array}$ \\
Költségvetés, pénzügyi tervek, elszámoló árak
\end{tabular}

Forrás: Dobák 20.0.

A koordinációs eszközök típusai közül a személyorientált típusra szükséges felhívni külön a figyelmet, amely a humán menedzsment tudományával szoros kapcsolatban áll. Ez azért is fontos, mert a költségvetési intézmények esetén az adott szolgáltatás minősége legnagyobb hányadban az emberi tényezőtől (tehát nem a gépek hatásfokától) függ. Adott szervezetben többek között a dolgozók optimális munkavégzésére (beleértve a továbbképzéseket stb.) a szervezési elméleteken túl, épp a humán menedzsment kíván 
választ adni. Ez a tơrekvés még az egyes vállalatok olyan egysége esetén is tetten érhető, ahol az emberi tényezö szerepe (a nagyfokú automatizáció következtében) egyre csekélyebben mutatható ki. Ezzel kapcsolatosan olyan elméletek születtek, mint a Total Quality Management, ahol a teljes, totális minőség elérése a cél. A dolgozókat újfajta mérési és jutalmazási rendszerrel ösztönzik a minél jobb minőség elérésére. A selejtet szankcionálják. A minőség 99,997\%-os, ez az úgynevezett 6. szigma szint elérése.

Hasonló a Just in Time rendszer, ahol a termelés nem raktárra történik, hanem a terméket igen rövid időn belül megrendelésre szállitjảk. Itt a dolgozókat gyors és pontos munkára ösztönzik, de legfontosabb a határidö betartása.

$\mathrm{Az}$ egyértelmünek tünik, hogy költségvetési intézmények esetén a közigazgatásban alkalmazott személyzeti politika nem alkalmas a dolgozók tevékenységeinek optimalizálására, a racionálisabb múködés elérésére. Ugyanakkor a szervezéstudomány és a humán menedzsment által alkotott - és a gyakorlatban is alkalmazható - elvek, nézetek még csak nyomokban sem fordulnak elö a költségvetési intézmények többségében. Ennek egyik oka talán a menedzsment hiánya.

Összegezve elmondható, hogy szükség van a költségvetési intézményekben alkalmazható szervezési elvek kidolgozására, az ehhez esetlegesen kapcsolódó szervezeti keretek kialakítására, az ágazati jogszabályok (pl. közoktatásról szóló törvény) felülvizsgálatára, kibövitésére. Ennek kapcsán szükséges szólni az előkészületben lévő non-profit törvényröl, amely feltehetöleg alkalmas lesz az önkormányzati feladatokat ellátó intézmények problémái egy részének megoldására, akár az intézmények átalakulása útján is.

\section{Az empirikus vizsgálatok eredményei}

A kutatás egyik kiindulópontja az volt, hogy az ellátás tekintetében reprezentálja az egyes telepưlések között fennálló különbségeket. Ennek érdekében egymástól eltérỏ lakosságszámú települések vizsgálatára került sor, a kisközségektől egészen a nagyvárosi szintig.

A vizsgált településeken költségvetési intézményeken kívül más formában (például alapítvány), önkormányzati feladat ellátása nem történik. Ez alól részben kivétel kettó város, ahol az alapítványt a nagyrészt önkormányzati érdekeltségú városüzemeltetéssel foglalkozó kft. hozta létre azzal a céllal, hogy segítse a müvelödési intézményeket. A másik esetben a mozgáskorlátozottak foglalkoztatására jött létre alapítvány. E szerveződésekről a város pénzügyi vezetése jelen pillanatban úgy vélekedik, hogy a város számára inkább terhet jelentenek (folyamatos támogatást igényelve), mint sem feladatok ellátásától szabadítanák meg az önkormányzatokat. Úgy tünik hogy, az önkormányzatok kevéssé keresik a kapcsolatot a lakossággal vagy a társadalmi szervekkel, holott segítségúkkel talán könnyebb lenne a jelenlegi intézmények kereteit átalakitani, a gazdaságosabb és talán szakmailag is jobban megalapozott és kontrollálható müködés érdekében.

\section{Iskolák}

Az önkormányzatok költségvetésük legnagyobb részét intézményeik fenntartására fordítják. Az intézmények közül kiemelkednek az iskolák, amelyek igen jelentös pénzeszközöket kötnek le. Az egyik város esetén ez az összeg az összköltségvetés 32,6\%a. A másik város esetén ez az arány $32,5 \%$ (az összköltségvetés 1,1 milliárd $\mathrm{Ft}$, ebböl az 
iskolák költségvetése 358 millió Ft.) Az egyik körjegyzőség központú község esetén az iskolára fordított összeg $24 \%$ (az összköltségvetés 900 millió $\mathrm{Ft}$, ezen belül az iskola költségvetése 3,5 millió Ft.) Egy önálló község esetén ez az összeg 10.696.000 Ft, a kỏltségvetés (128 millió Ft) 42\%-a. A fent említett ráfordításoknak keretet szabnak a helyi sajátosságok, azaz a tanárok és a diákok számaránya, valamint a feltétlenül szükséges dologi ráfordítások.

Ez a két finanszírozási elem jelenleg kihasználatlan racionalizálási lehetőségeket takar, amelynek megvalósítása már egy más jellegủ struktúra keretei kőzött lehetne optimális.

Nézzük azokat az adatokat, véleményeket, amelyek alapján ilyen következtetések vonhatók le:

1. Az oktatási intézmények költségvetési igényüket a lehetőségekhez képest túltervezik, amelyet az önkormányzat testülete alaposan lefarag. Így a költségvetés közel 80\%-át a bérek kifizetésére fordítják.

2. Külön problémát jelent az önálló gazdálkodású intézményeknek hogy a túlórákat, valamint a tanárok nyári fizetéskuilönbözetét maguknak kell kigazdálkodniuk. Ez különösen ott kedvezôtlen, ahol a tanári kar idősebb átlagkorú, itt ugyanis kialakult a szolgálati időhöz rendelt munkadíj, amely nyilván az idősebb tanárok drágább óraadását jelenti, amely a nem finanszírozott túlórák esetén fokozottan negatív a költségvetésủkre nézve.

3. Városi szinten gazdaságilag az önállóság is hátrányos, ugyanis a korábbi gameszok létszámához képest, e tevékenységet ellátó személyzet létszáma megkétszereződött, ugyanakkor a korábbi specializáció sem vált biztosítottá. Az önállóság pozitiv oldala az adott iskola gondjainak közelebbi ismerete. A gazdasági vezetés eredményessége fỏként a vezető személyes képességeitól függ, amely azonban nincs kapcsolatban a profit vagy non-profit szférában alkalmazott vezetési szervezési elvekkel.

4. További probléma a demográfiai hullámvölgy következtében elöállott tanári munkaerőtöbblet. Ez leginkább a városokban érzékelhető, míg a vizsgảlt községek egyikében látható volt a tanárok bizonyos túlterhelése, amire a túlórák számából következtethettünk.

5. Az egyik vizsgált városban az iskola gazdasági vezetóje túlzottnak ítélte meg az osztályok nyelvi bontását, amelynek következtében 10 fô alatti (néha pár fôs) csoportok jöttek létre.

6. Mindkét városban általános vélemény volt az önkormányzati, illetve gazdasági vezetés nézôpontjából a tanárok alulfoglalkoztatottsága. Ennek felszámolására a létszámcsökkentés kézenfekvőnek tünik, azonban a kifizetendő végkielégítés az adott intézmény költségvetését érzékenyen érinti.

7. Felvetődött a délutáni oktatás bevezetése, amelynek következménye lenne a tanárok, az épületek jobb kihasználtsága egybekötve egy-két iskola összevonásával.

8. Az intézmények költségvetésének fennmaradó $20 \%$-a fedezi a dologi ráfordításokat, amelyek az idösebb épületek esetén alig elegendöek a feltétlenül szükséges felújításokra. Az oktatási intézmények forrásait szemügyre véve - leszámítva az önkormányzati finanszírozást - általánosan megállapítható, hogy az intézmények törekednek a birtokukban lévő eszközöket haszonszerzés céljára is kihasználni. Ez adott esetben csaknem optimálisan történik (az iskola majd minden lehetőségét hasznosítja) más esetekben az ilyen hajlandóság mérsékelten jelentkezik. Ez a hajlandóság fóként az intézmény gazdasági szemléletével áll összefüggésben. $\mathrm{Az}$ önálló gazdálkodású intézmények vezetői az elóirt képesítéssel ugyan rendelkeznek, 
viszont szinte egyáltalán nem ismerik a marketing, és a humán menedzsment tudomány olyan új eredményeit, amelyeket a piaci szektorban a gyakorlatban is alkalmaznak, továbbá jelenleg nem létezik olyan érdekeltségi rendszer, amely a vezetőket az intézmények racionálisabb müködtetésére ösztönözné.

A gazdaságilag nem önálló intézmények esetén még rosszabb a helyzet, hiszen az önkormányzat adott hivatalnoka közvetlenül még abban sem érdekelt, hogy az intézmény mind racionálisabban müködjön, arról nem is beszélve, hogy sokszor az ehhez szükséges képzettség is hiányzik.

$\mathrm{Az}$ intézmények forrásaik bővítése érdekében bérbe adják a rendelkezésükre álló edzötermet, sportcsarnokot, kisebb uszodát, étkeztetési lehetőségeiket maximálisan kihasználva más elöfizetők részére is szolgáltatnak ebédet.

Az ilyen profitorientált tevékenység elsősorban a városokban jellemzö, ott is azon intézmények vannak előnyben, amelyek vonzóbb szolgáltatásokkal rendelkeznek (szauna, uszoda). A tisztán helyiség bérleti igénybevétel az intézmény számára valódi bevételt minimálisan jelent, a fütés, világítás, a takarítószemélyzet költségei miatt. A községekben még erről sem beszélhetünk, mivel itt önmagában az dicséretes, hogy ilyen tevékenység folytatására sor kerül (karate klub, táncegyesület). Az intézmények saját szellemi kapacitásukat csak igen ritkán hasznosítják különböző kurzusok, nyelvtanfolyamok stb. szervezése útján.

A „piaci” bevételek kis szerepet töltenek be az intézmények költségvetéseiben. Így például egy 2,8 milliós költségvetési intézmény esetén a bevétel 220 ezer $\mathrm{Ft}$. Általánosságban a bevételek a költségvetés $1 / 10$-ét teszik ki.

A megkérdezett jegyzők, polgármesterek egyhangúan állítják, hogy az intézményeknek nem az ilyen tevékenység folytatása az elsődleges feladatuk. Arra már kevésbé fordítanak figyelmet, hogy az ilyen intézményi lehetóségek menedzselése, fokozottabb kihasználása, esetleg fejlesztése nagymértében segíthet az intézmény gondjain.

Az intézmények életében - a gazdálkodó szervekkel ellentétben sem alaki, szervezeti, szabályozási sem számottevő anyagi, finanszírozási jellegü változás nem történt. A hatékonyságot elsősorban figyelembe vevő tulajdonosi érdek - a sokféle érdek közül nem került közelebb az intézményekhez.

\section{Óvodák, bölcsödék}

$\mathrm{Az}$ óvodák, bölcsödék kihasználtsági foka a vizsgált településeken egyenlöre kielégítőnek nevezhető. Az egyik város esetén viszont óvoda, illetve csoport összevonásokra kerülhet sor tekintettel a csökkenö létszámra. Érdekes, hogy erre épp a város föként fiatalok által lakott modern részében látható példa, míg a város egyik idősebbek által lakott területén - ahol igen sok alacsony jövedelmü család talált otthont az óvodák kihasználtsága teljes.

$\mathrm{Az}$ óvodák költségvetésének készítésekor az önkormányzat még nem ismerheti azt a tényleges létszámot, amely a szolgáltatást igénybe fogja venni. Ezért a számítások során a tárgyévi létszám 8/12-ét, valamint az elöző évi létszám 4/12 részét veszik alapul. Ezt az év végén felülvizsgálják és korrigálják a valós helyzetnek megfelelően. Az így 1 före kapott állami normatív támogatás nem fedezi a tényleges költségeket.

A vizsgált városban az óvodák és bölcsődék összköltségvetése 138548 ezer Ft volt. Ebböl élelmezésre 27700 ezer Ft-ot költöttek. Az élelmezési térítési dijakból, valamint szolgáltatásokból befolyt összeg 17535 ezer Ft. Látható, hogy az intézmények csaknem 
egyedüli profitszerzésre alkalmas tevékenysége több mint 10 milliós hiánnyal zárt. A költségvetésben a továbbiakban csak olyan tételek szerepelnek, amelyek az intézmények létezéséhez szükségesek. Irodaszerre, védöruhára, szakmai anyagokra semmi pénz nem áll rendelkezésre.

Az intézmények - bár részben önálló gazdálkodási státusszal rendelkeznek - vezetői között az elmúlt 4-5 év alatt nem történt gazdasági szemléletváltozás. Legtöbb esetben továbbra is a fenntartótól várják a gazdasági jellegủ kérdések eldöntését, az intézmény teljes körü fenntartását, gyakran az intézmény müködéséért érzett felelősség nélkül.

Hiányolhatók az olyan non-profit szervezetek, amelyek közvetlen ráhatást gyakorolhatnának az intézmények (gazdasági) problémáira. E szervezetek léte esetén többek között képviselethez juthatnának a szülök, akiket ezáltal könnyebben be lehetne vonni az intézményeket érintő gondok megoldásába (egy szülő által kicserélt csaptelep nem kerül pénzbe, míg ugyanezért a Városgazdálkodási Rt. kétezer Ft-ot kért, amelyböl a kiszállás magában ezer $\mathrm{Ft}$ volt). Az ilyen szervezetek - legitimációjuk révén meggyözhetnék az elutasítás indokairól az olyan igénylöt (igénylöket), aki(k) munkanélküli(ek) és ezért a gyerekek otthoni ellátása biztosított. Elfogadtathatnák az intézményi dolgozókkal, hogy ne csupán az általuk fogyasztott étel 67\%-át - hanem csakúgy, mint a gyerekek - az étkeztetés $100 \%$-át fizessék ki.

Végeredményben a non-profit szervezetek racionálisabb gazdálkodása a lehetöségek hatékonyabb kihasználására késztethetnék az intézmények vezetőit.

\section{Szociális otthonok}

A vizsgált községek nem, a városok viszont müködtetnek szociális otthont. Az otthonok kihasználtsága $100 \%$-os, sö́t jelen pillanatban is 46 személy vár felvételre. Az otthonok lakói nyugdijuk $80 \%$-át legfeljebb, 14.000 Ft-ot kötelesek térítési díjként az otthon részére átadni. Ha ez minden egyes igénybevevő esetén megvalósulna, úgy ez a normativával kiegészített összeg teljesen fedezné az intézmény költségeit. Az esetek egy részében ilyen magas dij beszedésére nincs lehetóség, sem az igénybevevőtöl, sem pedig tartására kötelezett hozzátartozójától. A hiányt az intézmények igyekeznek a költségek csökkentésével (pl. csak legfontosabb gyógyszerek rendelkezésre bocsátása) mérsékelni. Emellett kialakitanak több szobából álló olyan részlegeket, amelyeket - magasabb igények kielégítésével egyidejüleg - minimum 21000 Ft-ért bocsátanak az igénybevevök rendelkezésére. Igyekeznek kihasználni az étkeztetésból eredő profitszerzési lehetőségeket is. Látható, hogy az intézményvezetés törekszik racionalizálni gazdasági tevékenységét, azonban profi menedzsment hiányában - amelyre egy non-profit szervezet is alkalmas lenne - sokkal kevésbé képes az idősek hozzátartozóit, illetve a helyi lakosságot, esetleg a vállalkozói szférát mozgósítani a gazdaságosabb müködtetés érdekében.

\section{A körzeti ellátást nyújtó intézmények problémái}

$\mathrm{Az}$ egyik város esetében a pénzügyi szakemberek kiszámították, hogy hány bejáró általános iskolást kell ellátnia a városnak az érintett települési önkormányzatok hozzájárulása nélkül. Ez az összeg 129 före 1889 ezer Ft volt.

Még ennél is kiélezettebb a helyzet a vizsgált kórház esetében. A tulajdonos város polgármestere végigjárta a vonzáskörzetben lévö önkormányzatokat a kórház rekonstrukciójához szükséges fedezet elöteremtéséért. Támogatást azonban - egy kisebb összegủ adománytól eltekintve - senkitől sem kapott. 
A kórház hasonlóan más intézményekhez nehéz anyagi körülmények között van. Ennek jelentöségét azonban talán az emeli, hogy a lakosság egésze viszonylag érzékeny a kórházi, orvosi ellátás minőségére.

A kórház gazdasági vezetése - többek között - az alábbi problémákat sorolta fel:

1.) betegforgalom szezonális, nyáron kevesebb, télen több a beteg, ugyanakkor télen a kiadások is nőnek, a finanszírozás azonban mindig 2 hónapos csúszással érkezik;

2.) emelkednek a müködéshez szükséges anyagok árai, egyes olcsóbb magyar termékek eltủntek a piacról, a jelzett gyógyszeráremeléshez támogatást nem kapnak;

3.) nincs meg a forrása a 13. havi illetménynek, az azonos kategóriába tartozó minőségileg eltérỏ munka elismerésének, a munkaköri pótléknak.

Ezek - és más - gondok mindannak ellenére fennállnak, hogy a kórház kihasználja profitálható lehetỏségeit, valamint önálló marketing politikát folytat. Így például a nem orvosi indikáció alapján végzett vizsgálatok dijából 1247 ezer Ft volt a bevétel, a vendég étkeztetésből 3302 ezer Ft, a bérbeadásból származó bevétel 416 ezer Ft. A kórház költségvetése 355208 ezer $\mathrm{Ft}$. Látható, hogy a profit irányú bevételek igen csekély szerepet $(1,12 \%)$ töltenek be a kórház költségvetésén belül.

A bevételek szűkössége miatt itt is elötérbe kerülnek a megtakaritási lehetőségek, például kedvezményeket nyújtó szerződéskötések. Létszámcsökkentést nem hajtottak végre, de a megüresedett helyeket nem töltötték be.

A város pénzügyi vezetése felveti magának a kórház létjogosultságának a kérdését. Ezt a gondolatot a kihasználtság viszonylag alacsonyabb fokára, valamint a közelben lévö nagyváros kórházainak igénybevehetőségére alapozza.

\section{Összefoglalás}

Kétségtelen, hogy vizsgálati tapasztalataink szerint a körzeti intézmények finanszírozása, igénybevétele, az érintett önkormányzatok tulajdonosi érdekeltsége tekintetében tapasztalható a legtöbb probléma. A jelenség jelzi, hogy a körzeti ellátásban az önkormányzatok megegyezését, a hatékonyabb munkamegosztást központi finanszírozási technikákkal és szabályozással kellene elösegíteni.

Jelen pillanatban a szolgáltatások túlnyomó részét állami, önkormányzati intézmények látják el, a szervezeti keretek csaknem teljes érintetlenül hagyása mellett. Ez az intézményi struktúra eredményezi a humán erőforrással és az anyagi eszközökkel történỏ kevésbé hatékony gazdálkodást, ennél feltehetőleg jobb megoldás lenne a non-profit szervezetek bevonása e feladatok ellátásába. Ennek okai többek között az alapítók eröteljesebb érdekeltsége, hatása a szolgáltatásokra, a menedzsment müködése, az fogyasztók és a szervezet közötti szorosabb kapcsolat.

Gazdasági és minőségi oldalról optimális keretet csak a tisztán piaci alapon müködő intézmények (például magániskolák) nyưjithatnak. Ez a típus viszont a fizetöképes kereslet hiánya miatt nem válhat általánossá.

A legkedvezőbb megoldás lehetne, ha az üzemeltetés egy részét a non-profit szféra venné át, vagy a jelenlegi intézményekben meghonosítanák azokat a szervezési elveket, amelyek - esetleg más szervezeti keretek között - az igények hatékonyabb kielégítését szolgálnák. 


\section{Irodalom}

Darázs I-né (1992) A helyi ơnkormányzatok gazdálkodása. Magyar Közigazgatás. 42. évf. 3.sz.

Dobák M. (1992) Szervezeti formák és koordináció. Kozgazdasági és Jogi Konyvkiadó, Budapest

Farkas F. (1995) A modern menedzsment elemei a non-profit szektor szervezeteiben. Non-profit Kutatócsoport Egyesulet Pécs-Budapest.

Horváth M. T. - Péteri G. (1993) Új változatosság: politikai keretek és gazdálkodási stratégiák az önkormányzatokban. Budapest: Helyi demokrácia és újítások alapítvány.

Kara P. (1994) Az onkormányzati gazdálkodás néhány súlyponti kérdése. Magyar Közigazgatảs. 44. évf. 2. sz.

Mádi Z. (1992) Önkormányzati gazdálkodás és a nagyvárosok. Magyar Közigazgatós. 42. évf. 8. sz.

Pálfi A. (1995) Feladatfinanszírozás az onkormányzatok gazdálkodásában Magyar Közigazgatás. 45. évf. 9. sz.

Péteri G. (1995) Önkormányzati gazdálkodás: Új lehetőségek gyakorlati módszerek. Budapest: Helyi demokrácia és újítások alapitvány 1995.

Péteri G. (1991) Az önkormányzatok és oktatósi intézményeinek viszonya, finanszírozási kérdések. In: Önkormányzat és iskola. Szerk.: Kozma Tamás. Budapest: Oktatáskutató Intézet 1991.

Vogler I. (1990) Önkormányzatok költségvetési joga és gazdálkodása Bajorországban. Pénzügyi Szemle 8-9. sz.

\section{Abstract}

The reform of the state budget, the formation of non-profit organisations and the unfavourable economic situation of local governments and their institutions raise many problems which have not been so sharp before, this way evading the attention of the experts.

The purpose of the study is to show, with the help of empirical researches, the problems which are generally typical of the most important institutions of local governments. A medium sized and a small town with a small population, also four villages with varying numbers of population were examined, with respect to the expenditure and everyday operation of their local governments and institutions.

According to our findings, most of the problems can be seen in the financing and utilisation of small regional institutions and the ownership interests of the local governments concerned. This phenomenon shows that in small regional provision, the agreement of the local governments and a more efficient division of labour should be achieved by central financing techniques and regulation. 